Article

\title{
Development by Design in Western Australia: Overcoming Offset Obstacles
}

\author{
James Fitzsimons $^{1{ }^{*} \text {, Michael Heiner }}{ }^{2}$, Bruce McKenney ${ }^{3}$, Kei Sochi ${ }^{4}$ and Joseph Kiesecker ${ }^{2}$ \\ 1 The Nature Conservancy, Suite 2-01, 60 Leicester Street, Carlton, VIC 3053, Australia \\ 2 The Nature Conservancy, 117 East Mountain Avenue Suite 201, Fort Collins, CO 80524, USA; \\ E-Mails: mheiner@tnc.org (M.H.); jkiesecker@tnc.org (J.K.) \\ 3 The Nature Conservancy, 490 Westfield Road, Charlottesville, VA 22901, USA; \\ E-Mail: bmckenney@tnc.org \\ 4 The Nature Conservancy, 2424 Spruce Street, Boulder, CO 80302, USA; \\ E-Mail: ksochi@tnc.org \\ * Author to whom correspondence should be addressed; E-Mail: jfitzsimons@tnc.org (J.F.); \\ Tel.: +613-8346-8604; Fax: +613-8346-8620.
}

Received: 14 November 2013; in revised form: 7 February 2014 / Accepted: 13 February 2014 / Published: 20 February 2014

\begin{abstract}
Biodiversity offsets can be an important tool for maintaining or enhancing environmental values in situations where development is sought despite negative environmental impacts. There are now approximately 45 compensatory mitigation programs for biodiversity impacts worldwide, with another 27 programs in development. While offsets have great potential as a conservation tool, their establishment requires overcoming a number of conceptual and methodological hurdles. In Australia, new policy changes at the national and state (i.e., Western Australia) level require that offsets follow a set of general principles: (1) Environmental offsets may not be appropriate for all projects and will only be considered after avoidance and mitigation options have been pursued; (2) Environmental offsets will be based on sound environmental information and knowledge; (3) Establishing goals for offsets requires an estimate of expected direct and indirect impacts; (4) Environmental offsets will be focused on longer term strategic outcomes; (5) Environmental offsets will be cost-effective, as well as relevant and proportionate to the significance of the environmental value being impacted. Here we focus on the challenges of determining and implementing offsets using a real world example from a voluntary offset process undertaken for Barrick Gold's Kanowna Belle mine site in Western Australia to highlight those challenges and potential solutions.
\end{abstract}


Keywords: mitigation hierarchy; offsets; Great Western Woodlands; mining; Western Australia; pastoral lease

\section{Introduction}

Biodiversity offsets are one important tool for maintaining or enhancing environmental values to mitigate the negative environmental impacts of development [1-3]. Offsets are intended as an option for addressing environmental impacts of development after efforts to minimize impacts on-site through application of the other steps of the mitigation hierarchy: avoid, minimize, and restore [4]. They seek to ensure that inevitable negative environmental impacts of development are balanced by environmental gains, with the overall aim of achieving a net neutral or positive outcome.

Offset policies for environmental purposes have gained attention in recent years (i.e., [5,6], see [3] for a review). Although the use of offsets remains relatively limited, offsets are increasingly employed to achieve a range of environmental benefits, including pollution control, mitigation of wetland losses, and protection of endangered species $[1,3]$. The cumulative influence of advancing these policies is large and growing (i.e., [7,8]), and interest in offsets is not only restricted to governments. Multinational corporations such as Rio Tinto [9] aim to have a "net positive impact on biodiversity" as part of their biodiversity strategy, and offsets are likely play an important role in meeting this objective. In addition, major financial institutions such as the IFC and the 70 private financial institutions that have adopted the Equator Principles are requiring that project developers offset residual impacts with the goal of either "no-net-loss" or "net-positive-impact" for biodiversity [8].

There are now approximately 45 compensatory mitigation programs for biodiversity impacts worldwide, with another 27 programs in development [7]. While offsets have great potential as a conservation tool, their establishment requires overcoming a number of conceptual and methodological hurdles $[3,10]$. Increasingly, policies and regulations at international, national and state levels include a number of key principles for biodiversity offsets from development approvals. These principles include (but are not limited to): (1) considering offsets after avoidance and mitigation options have been pursued first; (2) basing offsets on sound environmental information and knowledge; (3) being relevant and proportionate (in size and scale) to the environmental value being impacted and focused on longer term strategic outcomes; (4) accounting for and managing the risks of the offset not succeeding; (5) being additional to what is already required, determined by law or planning regulations, or agreed to under other schemes or programs; and (6) being efficient, effective, timely, transparent, scientifically robust, measurable and reasonable $[7,11,12]$.

Many of these policy changes are being driven by development booms. For example in Australia, national, state and territory governments have revised mitigation/offset polices in response to expected increases in application licenses. Here we define a set of general offset principles (Table 1) and use a case study in the Australian State of Western Australia as a way to highlight barriers that may hinder successful offset implementation. Case study literature pertaining to mine site offsets are rare [13]. 
Table 1. Principles for the use of environmental offsets for the Australian and Western Australian Governments [11,12] and consolidated principles adapted for this paper

\begin{tabular}{|c|c|c|}
\hline $\begin{array}{l}\text { Australian Government: Environment } \\
\text { Protection and Biodiversity } \\
\text { Conservation Act } 1999 \text { Environmental } \\
\text { Offsets Policy }\end{array}$ & $\begin{array}{l}\text { Western Australian } \\
\text { Environmental Offsets Policy }\end{array}$ & $\begin{array}{c}\text { Consolidated Principles Used in } \\
\text { This Paper; Adapted from } \\
\text { Australian and Western } \\
\text { Australian Principles } \\
\end{array}$ \\
\hline $\begin{array}{l}\text { 1. Suitable offsets must deliver an overall } \\
\text { conservation outcome that improves or } \\
\text { maintains the viability of the } \\
\text { protected matter. }\end{array}$ & $\begin{array}{l}\text { 1. Environmental offsets will only be } \\
\text { considered after avoidance and } \\
\text { mitigation options have } \\
\text { been pursued. }\end{array}$ & $\begin{array}{l}\text { 1. Environmental offsets may not be } \\
\text { appropriate for all projects and will } \\
\text { only be considered after avoidance } \\
\text { and mitigation options have } \\
\text { been pursued. }\end{array}$ \\
\hline $\begin{array}{l}\text { 2. Suitable offsets must be built around } \\
\text { direct offsets but may include other } \\
\text { compensatory measures. }\end{array}$ & $\begin{array}{l}\text { 2. Environmental offsets are not } \\
\text { appropriate for all projects. }\end{array}$ & $\begin{array}{l}\text { 2. Environmental offsets will be } \\
\text { based on sound environmental } \\
\text { information and knowledge. }\end{array}$ \\
\hline $\begin{array}{l}\text { 3. Suitable offsets must be in proportion to } \\
\text { the level of statutory protection that applies } \\
\text { to the protected matter. }\end{array}$ & $\begin{array}{l}\text { 3. Environmental offsets will be } \\
\text { cost-effective, as well as relevant and } \\
\text { proportionate to the significance of } \\
\text { the environmental value } \\
\text { being impacted. }\end{array}$ & $\begin{array}{l}\text { 3. Establishing goals for offsets } \\
\text { requires an estimate of expected } \\
\text { direct and indirect impacts. }\end{array}$ \\
\hline $\begin{array}{l}\text { 4. Suitable offsets must be of a size and } \\
\text { scale proportionate to the residual impacts } \\
\text { on the protected matter. }\end{array}$ & $\begin{array}{l}\text { 4. Environmental offsets will be } \\
\text { based on sound environmental } \\
\text { information and knowledge. }\end{array}$ & $\begin{array}{l}\text { 4. Environmental offsets will be } \\
\text { focused on longer term } \\
\text { strategic outcomes. } \\
\text { 5. Environmental offsets will be }\end{array}$ \\
\hline $\begin{array}{l}\text { 5. Suitable offsets must effectively account } \\
\text { for and manage the risks of the offset } \\
\text { not succeeding. }\end{array}$ & $\begin{array}{l}\text { 5. Environmental offsets will be } \\
\text { applied within a framework of } \\
\text { adaptive management. }\end{array}$ & $\begin{array}{l}\text { cost-effective, as well as relevant } \\
\text { and proportionate to the significance } \\
\text { of the environmental value } \\
\text { being impacted. }\end{array}$ \\
\hline $\begin{array}{l}\text { 6. Suitable offsets must be additional to } \\
\text { what is already required, determined by } \\
\text { law or planning regulations, or agreed to } \\
\text { under other schemes or programs. } \\
\text { 7. Suitable offsets must be efficient, } \\
\text { effective, timely, transparent, scientifically } \\
\text { robust and reasonable. } \\
8 \text {. Suitable offsets must have transparent } \\
\text { governance arrangements including being } \\
\text { able to be readily measured, monitored, } \\
\text { audited and enforced. }\end{array}$ & $\begin{array}{l}\text { 6. Environmental offsets will be } \\
\text { focused on longer term } \\
\text { strategic outcomes. }\end{array}$ & \\
\hline
\end{tabular}

Our objective for the project was to design an approach that ensures offset options are ecologically equivalent to impact sites, will persist at least as long as on-site impacts, and will achieve no net loss or positive outcomes. The analysis described here was intended to support Barrick Gold, one of the world's largest gold mining companies, as they seek to implement their biodiversity standard to better manage, mitigate, and offset biodiversity impacts [14]. Barrick's biodiversity standard, developed in 2009, requires Barrick to "integrate biodiversity into project planning and decision-making, to assess the direct and indirect impacts of new projects (and expansions of existing projects) on ecosystem 
services, to design projects that avoid potentially significant impacts on biodiversity, to exploit opportunities to protect and enhance biodiversity, to consult with stakeholders and to engage in partnerships that address scientific and practical challenges relating to biodiversity protection or enhancement". The Standard applies from exploration through mine closure with the goal of "no net loss to biodiversity" [15]. Offsets are a key tool under the Barrick standard, providing for specific conservation or enhancement activities that can compensate for the loss of biodiversity. Below we give an overview of the Development by Design process used to implement the process at Barrick's Kanowna Belle operations. Many studies have outlined the offset design process [16-20], and our intention here was not to do an in depth review of these methodologies. Instead, in this paper we focus on the challenges of determining and implementing offsets using a real world example to highlight those challenges and potential solutions. More specific details on the analysis used to determine offset options are presented elsewhere [21]. We used the principles based on the recent policy changes in Australia to guide our process and structure this paper (Table 1).

\section{Study Area}

This project focused on finding suitable offsets for Barrick Gold's Kanowna Belle mine operations, located to the north west of Kalgoorlie (30³6'16"S, 121 $\left.{ }^{\circ} 34^{\prime} 36^{\prime \prime E}\right)$, and within the Great Western Woodlands, in south-central Western Australia. The Great Western Woodlands is the largest remaining intact temperate or "Mediterranean" woodland in the world. The area covers almost 16 million hectares and is a continuous band of vegetation spanning the edge of the Western Australian "Wheatbelt" to the Mulga country in north through to the inland deserts to the northeast and the Nullarbor Plain to the east (Figure 1). This significant area of eucalypt woodlands is intermixed with thicker eucalypt mallee, low shrublands, and grasslands. The very high plant diversity within these vegetation types (over 3,000 species being recorded to date, with high rates of endemism), is one of the primary reasons for the region's conservation significance. Across the landscape, these species change rapidly, many occurring only in localized areas, creating a mosaic of ecological communities throughout the region [22]. The woodlands are also highly prospective, with minerals such as gold, nickel and copper associated with the greenstone belts, with exploration permits covering $62 \%$ of the Great Western Woodlands and active mining leases covering 3.8\% in 2011. The Kanowna Belle mine operations lie in Coolgardie bioregion and the north-western corner of the East Goldfields subregion, where the Coolgardie transitions northward into the Murchison bioregion [23]. The Coolgardie bioregion forms roughly the northern and western boundary of the Great Western Woodlands (Figure 1).

Kanowna Belle is a gold mine with mining in open pit operation starting in 1993. Barrick estimates the mine will close in 2016. The pits and tailings cover 1,294 ha within which all vegetation has been cleared, while the total tenements for the mine operations comprise approximately 66,600 ha. 
Figure 1. Study area overview map showing the Barrick/Kanowana mine sites and pastoral leases, the IBRA bioregions and the Great Western Woodlands.

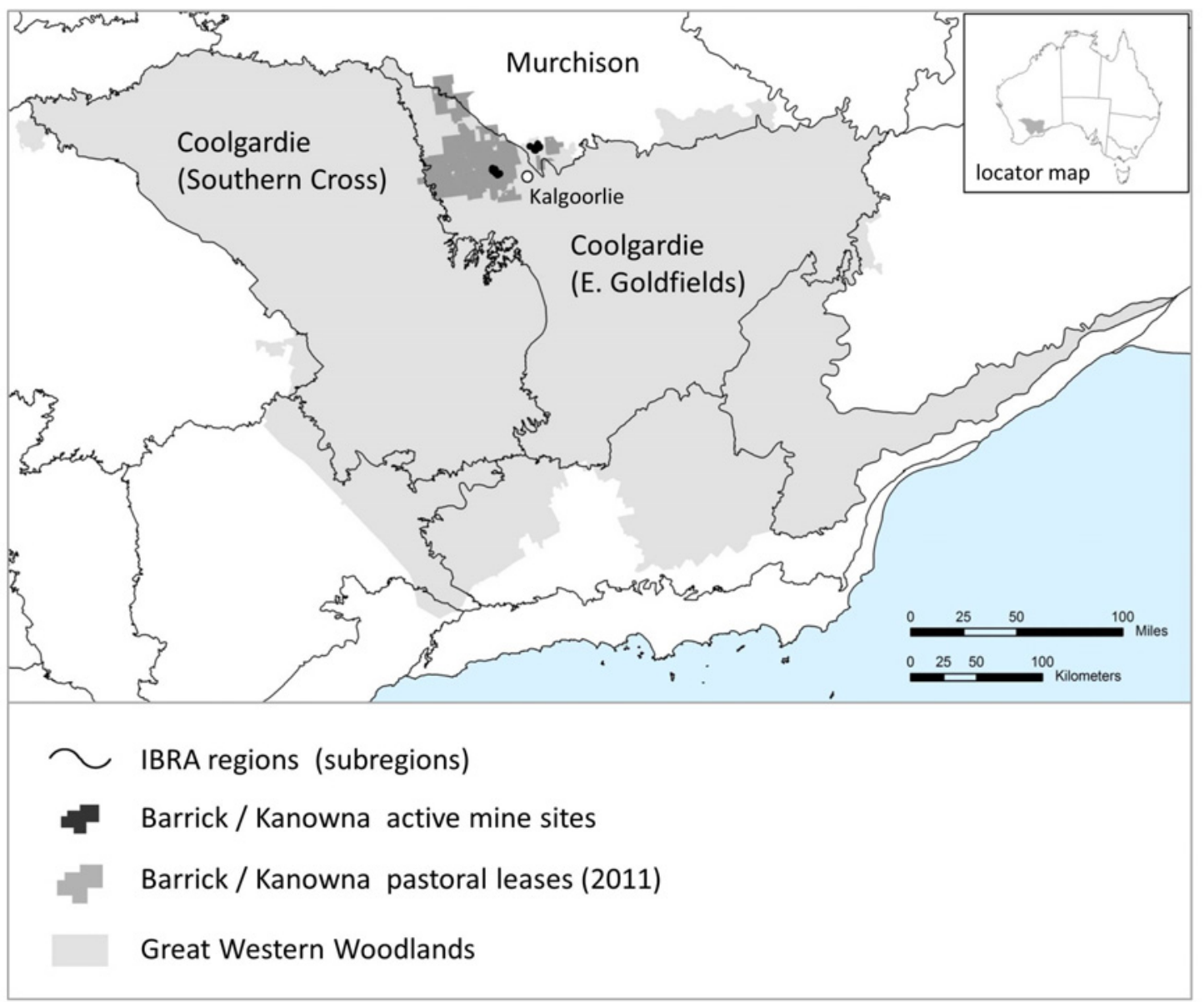

\section{Applying Offset Principles to the Great Western Woodlands}

Our process, and the structure of this paper, is organized around the five principles described in Table 1. These principles are based on recent policy changes in Australia and are used to guide our process and structure this paper. We addressed these principles though an adaptation of The Nature Conservancy's Development by Design process. Development by Design is a science-based mitigation planning process that seeks to bring efficiencies to development planning and impact mitigation, while achieving effective conservation that encourages "no net loss" of biodiversity values. Development by Design seeks implementation of the "mitigation hierarchy" — avoid, minimize/restore, and offset —in a way that is transparent. Development by Design is applied at two distinct spatial scales: first at a landscape level to evaluate conservation priorities, assess cumulative impacts in the region, and ensure conflicts between conservation priorities and development conform to the mitigation hierarchy [24,25]; and second at a project level to assess site-level biodiversity impacts and design an offsets strategy for mitigating these impacts [16,26]. The process and offset options do not address air, water or soil quality issues that may occur at, or emanate from, the Kanowna Belle operation; nor should it be considered to relieve Barrick of legal responsibilities in relation to these (e.g., [27]) and other obligations (e.g., future mine-site closure) under state or national government laws or regulations. 


\subsection{Principle 1. Environmental Offsets may not be Appropriate for all Projects and will only be} Considered after Avoidance and Mitigation Options Have Been Pursued

The offset analysis of the Kanowna Belle operations considered only existing impacts. Because the Kanowna Belle mine is an existing project, it was not possible to make recommendations on how impacts could be avoided or minimized in this instance. Nonetheless, for proposed developments on greenfields sites or expansion of existing operations this is an essential principle.

While mitigation frameworks require developers to avoid, minimize and restore biodiversity on-site before considering an offset for residual impacts, there is a lack of quantitative guidance for this decision-making process. There is broad agreement among scholars, scientists, policymakers, and regulators that the first and most important step in the mitigation hierarchy, avoidance, is ignored more often than it is implemented (i.e., [28]). Developing criteria to determine whether impacts should be avoided altogether will be a key challenge when offsets are an available option, as there are limits to what can be offset [29].

The question of when project impacts should be avoided can be informed through the use of systematic conservation planning [30]. For new proposed projects, potential impacts could be examined as part of a systematic conservation planning exercise within the context of future development (i.e., [24,31,32]). Proposed projects, along with projected development activities, can be mapped and assessed relative to existing conservation priorities or incorporated in the development of a new conservation plan [24,33,34]. Whenever possible, development patterns should be designed within a framework that takes into account conservation goals for healthy ecosystems (see for example [26]). Following this approach, conflicts between conservation priority areas and development impacts can be addressed by redrawing the conservation priority areas to recapture habitat elsewhere in the study area to meet minimum viability needs of target species and ecological systems. However, if conservation goals cannot be met through redrawing of conservation priorities, development impacts must be minimized to the degree that biodiversity values are maintained or impacts must be avoided [24].

\subsection{Principle 2. Environmental Offsets will be Based on Sound Environmental Information and Knowledge}

Key to any offset design process should be the incorporation of the best available environmental information. To address this issue we formed a mitigation-design working group to guide the development of the analysis and integration of spatial data into the offset design process. Participants were selected because they had expertise on the biological systems affected by the Kanowna Belle operations and included representatives from Barrick Gold, state and federal government agencies, universities, local and regional non-government organisations and the local community. This group helped secure the most current spatial data on biological elements, assessments of any predictive models utilized, and insights into the process being developed.

To further ensure that we used the best possible information, we selected biodiversity elements that: (a) adequately represent the range of biological diversity in the project area; and (b) can be measured and mapped. Given the lack of geospatial data to comprehensively map the current range of species that are significant to the study area, we defined biodiversity elements following a coarse filter 
approach focused on terrestrial habitat. To define and map coarse-filter biodiversity elements, we used an existing vegetation classification, the National Vegetation Information System (NVIS) [35] and a map of surficial geology [36].

The NVIS is a mapped vegetation classification which for Western Australia is derived from maps of pre-European vegetation ([37], Figure 2). The classification is hierarchical, organized as six levels from vegetation class to plant sub-association. On the advice of the working group, we defined a set of biodiversity elements based on the NVIS Plant Associations (Level 5). The NVIS defines and maps 22 Plant Associations within the East Goldfields study area, of which 15 occur within the Kanowna Belle mine operations (Figure 2).

Figure 2. Habitat Types (NVIS plant associations) occurring within the mine footprint. We stratified plant associations by landforms to define and map 116 biodiversity elements across the study area, of which 71 occur within the mine footprint.

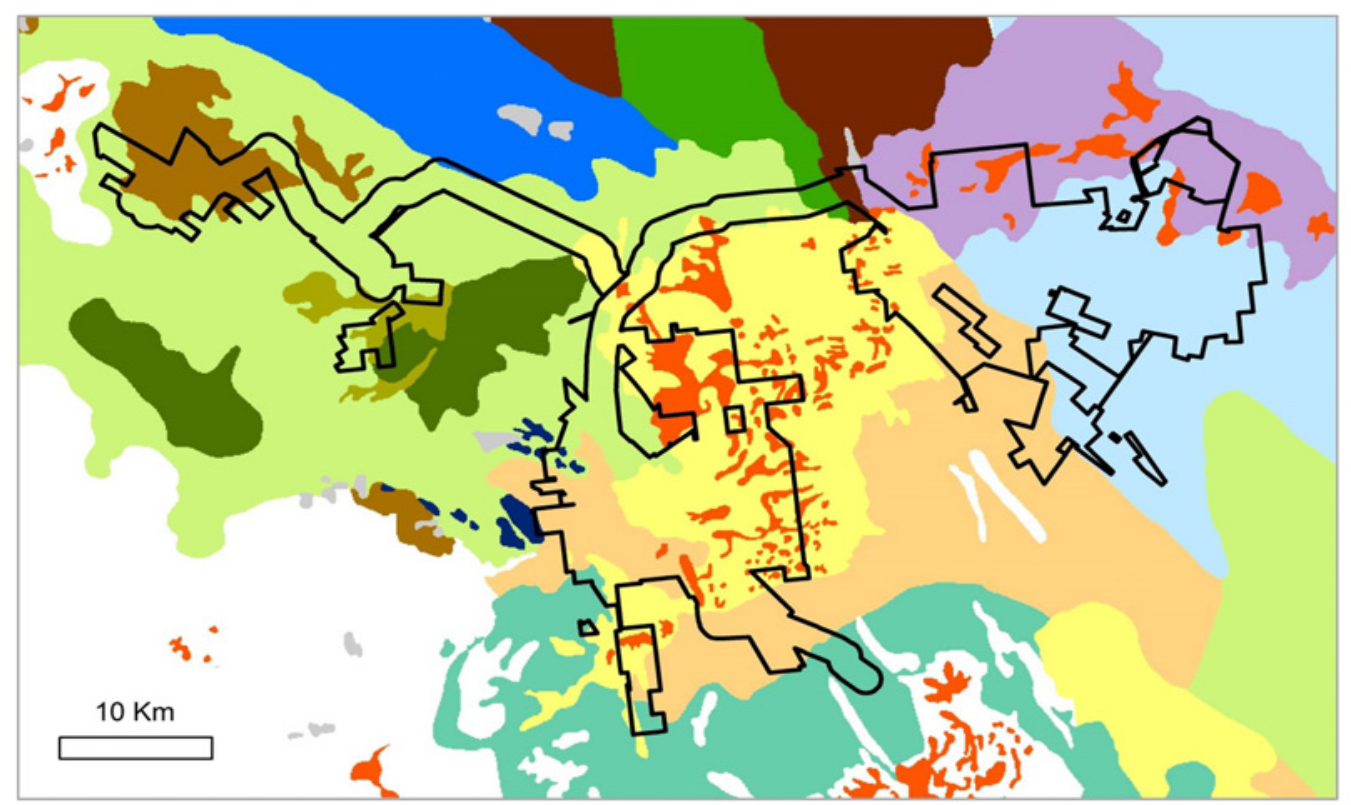

Kanowna Belle mine footprint (mine site and infrastructure)

\section{NVIS Plant Association (abbreviated name)}

1. Bare areas; rock outcrops

2. Bare areas; salt lakes

3. Maireana sp., Atriplex sp. Ichenopod

4. Casuarina cristata, M. platycarpum, C. columellaris \tree

5. Acacia aneura, C. columellaris, E. oleosa tree

6. Acacia quadrimarginea, A. acuminata, A. campestris \shrub

7. Acacia quadrimarginea $\backslash$ shrub

8. Allocasuarina sp. Itree; G Atriplex sp. Ichenopod

9. Eucalyptus le souefii, E. salmonophloia, E. transcontinentalis \tree

10. Eucalyptus oleosa, E. griffithsii, E. gracilis\mallee

11. Eucalyptus oleosa, E. transcontinentalis $\backslash$ tree

12. Eucalyptus salmonophloia, E. dundasii tree

13. Eucalyptus salmonophloia, E. lesouefii, E. salubris\tree

14. Eucalyptus salmonophloia\tree

15. Eucalyptus torquata, E. le souefii, E. clelandii tree area (ha) within mine footprint

$$
\begin{array}{r}
22 \\
6,065 \\
606 \\
17,906 \\
16,083 \\
128 \\
176 \\
5,178 \\
11,900 \\
3,580 \\
408 \\
14,004 \\
415 \\
175 \\
1,586
\end{array}
$$


Although species occurrence data were unavailable, we mapped physical habitat, or landforms, that represent potential variation important to species distributions. Many plant associations are widespread and broadly mapped, occupying a relatively large area in the East Goldfields and are usually a heterogeneous, patchy matrix of plant communities formed by topography, disturbance regimes and successional cycles. To capture this ecological variation, we stratified 18 of the 22 Plant Associations by landforms. We defined and mapped landforms (Figure 3) according to a cluster analysis of elevation, insolation [38] and a topographic index [39]. The result is 116 "focal elements" across the East Goldfields study area, of which 71 occur within the Kanowna Belle mine operations.

Figure 3. Landforms defined and mapped according to a cluster analysis of elevation, insolation [38] and a topographic index [39].

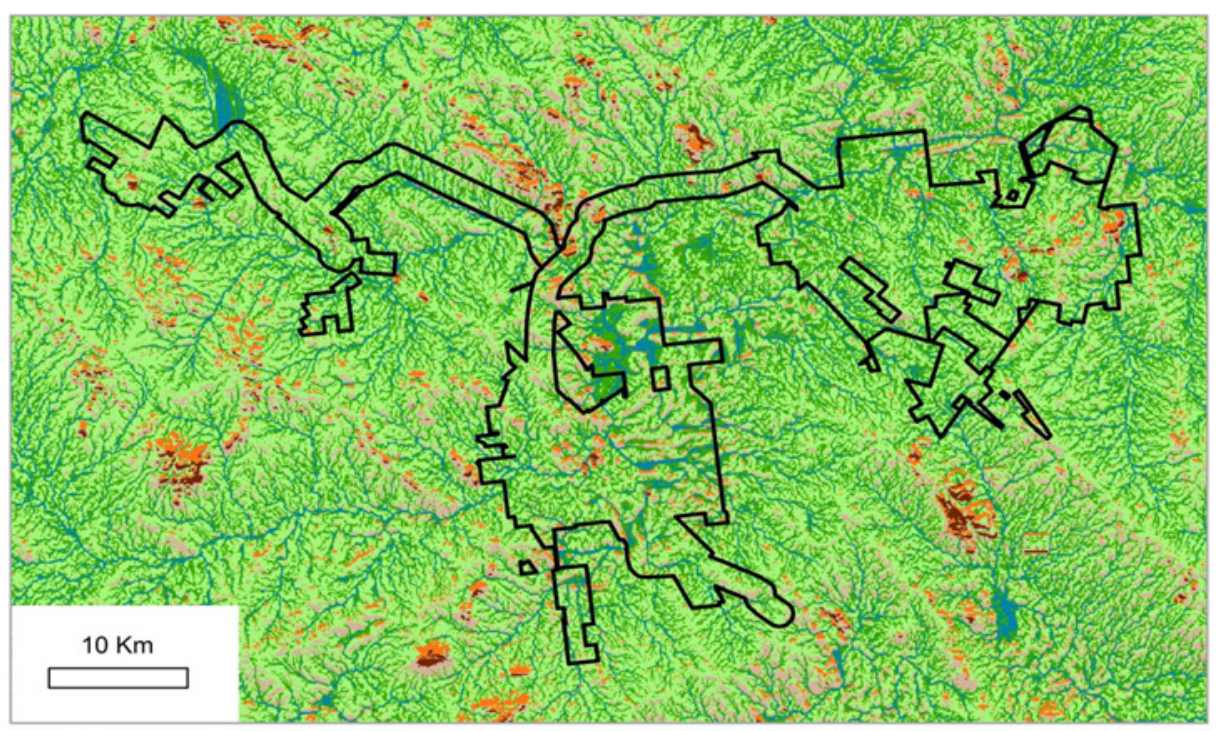

Kanowna Belle mine footprint (mine site and infrastructure)
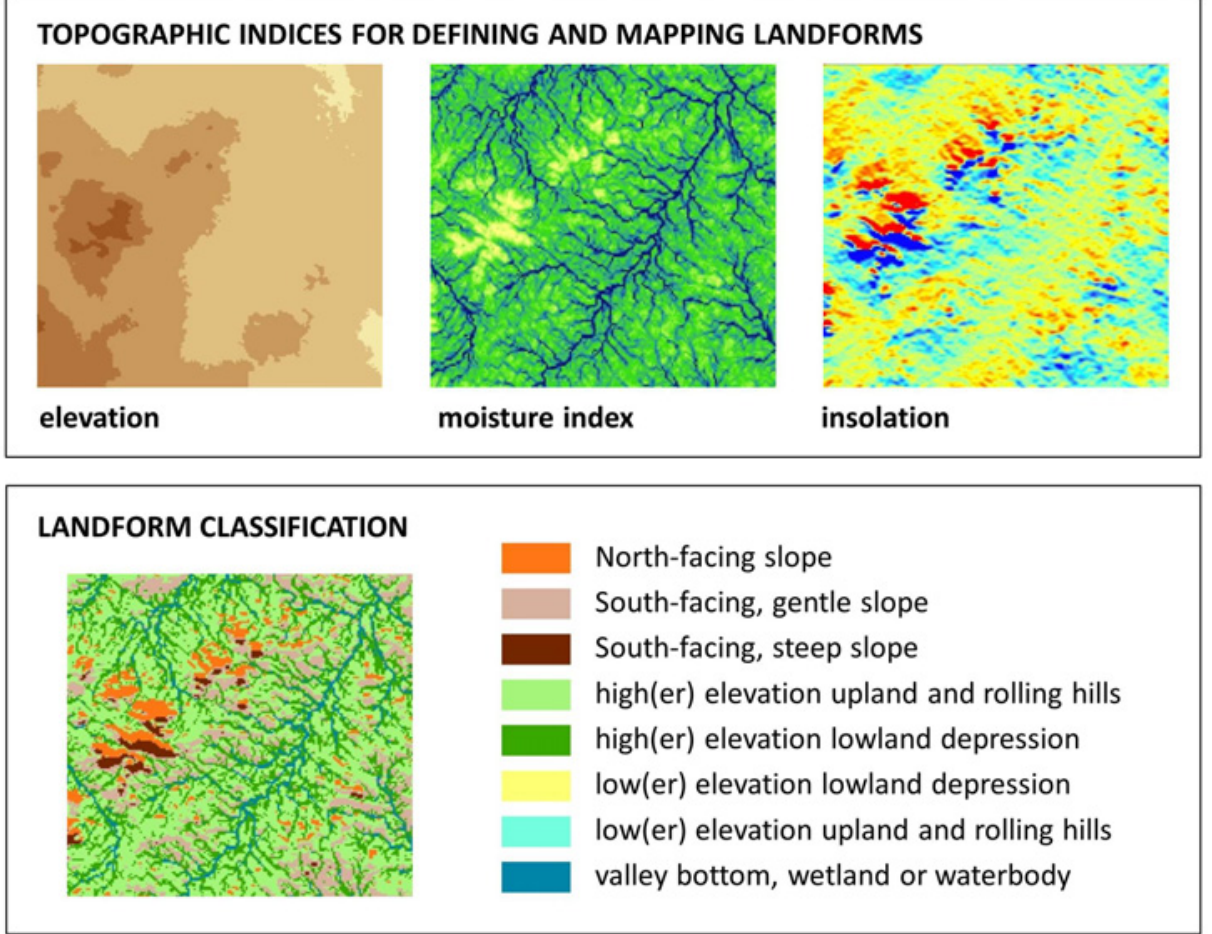
Patterns of surficial geology may capture and account for the habitat preferences of many animal species, in particular reptiles, which respond strongly to soils and physical habitat [40]. Therefore, we also defined biodiversity elements based on a map of surficial geology [36] that we re-classified to define and map 12 general lithology types across the East Goldfields subregion, and 10 within the Kanowna Belle mine footprint. Where species data is not available attempts to identify offset sites will have to develop surrogates that will be suitable for the context.

\subsection{Principle 3. Establishing Goals for Offsets Requires an Estimate of Expected Direct and Indirect Impacts}

Establishing goals for mitigation (i.e., what is necessary to offset impacts) first requires an estimate of expected direct and indirect impacts [19]. These impacts, which may be due to a proposed project, expanded resource use or, as with the case of Barrick's Kanowna Belle mine, the result of existing impacts, are analyzed at a site-level to understand the specific nature of potential impacts. This process often draws on environmental impact assessment information as well as information compiled (e.g., list of representative biological elements and spatial data) as part of a landscape conservation plan.

We calculated estimates of the spatial area affected by the Kanowna Belle mine and associated roads and activities. We estimated the development footprint with data provided by Barrick as well as data from Geoscience Australia and the Western Australian Department of Mines and Petroleum. For mine pits and tailings, and the connecting roads, we mapped a $1 \mathrm{~km}$ buffer to represent the approximate area of impact ([21], see also [41]). In total the estimated area of impact was calculated at 78,230 ha (Table 2). We then measured the area of each biodiversity element potentially affected by the mining operations (see Figure 2).

Table 2. Mine footprint components at Kanowna Belle mine operations.

\begin{tabular}{|c|c|c|c|c|c|c|}
\hline \multirow[b]{3}{*}{ Feature } & \multicolumn{4}{|c|}{ Area (ha) } & \multirow[b]{3}{*}{ Mapping Method } & \multirow[b]{3}{*}{ Source Data } \\
\hline & \multirow[b]{2}{*}{ Total } & \multicolumn{3}{|c|}{ Tenements } & & \\
\hline & & $\begin{array}{c}100 \% \\
\text { Owned and } \\
\text { Managed by } \\
\text { Barrick }\end{array}$ & $\begin{array}{c}\text { Barrick } \\
\text { Joint } \\
\text { Venture } \\
\text { Managed by } \\
\text { Barrick } \\
\end{array}$ & $\begin{array}{l}\text { Barrick Joint } \\
\text { Venture not } \\
\text { Managed by } \\
\text { Barrick }\end{array}$ & & \\
\hline \multicolumn{7}{|l|}{ Mine Site } \\
\hline Pits \& tailings & 1,294 & 1,234 & 60 & & $\begin{array}{c}\text { Selected features occurring } \\
\text { within Barrick mining } \\
\text { tenements }\end{array}$ & $\begin{array}{c}\text { GEODATA TOPO } \\
1: 250 \mathrm{k} \\
\text { (Geoscience } \\
\text { Australia) }\end{array}$ \\
\hline $1 \mathrm{~km}$ buffer & 8,124 & 6,685 & 1,425 & 13 & $\begin{array}{l}\text { Mapped } 1 \mathrm{~km} \text { buffer around } \\
\text { mine site }\end{array}$ & \\
\hline \multicolumn{7}{|l|}{ Transport } \\
\hline $\begin{array}{l}\text { Connecting roads and } \\
1 \mathrm{~km} \text { buffer }\end{array}$ & 20,992 & 17,061 & 2,545 & 1,386 & $\begin{array}{l}\text { Selected roads connecting } \\
\text { mine sites and occurring } \\
\text { within Barrick mining } \\
\text { tenements, mapped } 1 \mathrm{~km} \\
\text { buffer. }\end{array}$ & $\begin{array}{c}\text { GEODATA TOPO } \\
\text { 1:250 k } \\
\text { (Geoscience } \\
\text { Australia) }\end{array}$ \\
\hline
\end{tabular}


Table 2. Cont.

\begin{tabular}{|c|c|c|c|c|c|c|}
\hline \multirow[b]{3}{*}{ Feature } & \multicolumn{4}{|c|}{ Area (ha) } & \multirow[b]{3}{*}{ Mapping Method } & \multirow[b]{3}{*}{ Source Data } \\
\hline & \multirow[b]{2}{*}{ Total } & \multicolumn{3}{|c|}{ Tenements } & & \\
\hline & & $\begin{array}{c}100 \% \\
\text { Owned and } \\
\text { Managed by } \\
\text { Barrick }\end{array}$ & $\begin{array}{c}\text { Barrick } \\
\text { Joint } \\
\text { Venture } \\
\text { Managed by } \\
\text { Barrick }\end{array}$ & $\begin{array}{c}\text { Barrick Joint } \\
\text { Venture not } \\
\text { Managed by } \\
\text { Barrick }\end{array}$ & & \\
\hline $\begin{array}{c}\text { Tenement } \\
\text { (remaining area) }\end{array}$ & 47,820 & 17,650 & 10,979 & 19,190 & $\begin{array}{c}\text { Tenements classified by } \\
\text { management }\end{array}$ & $\begin{array}{c}\text { Tenement } \\
\text { boundaries: WA } \\
\text { Department of } \\
\text { Mines \& } \\
\text { Petroleum; Barrick }\end{array}$ \\
\hline Total area of impact & 78,230 & 42,630 & 15,010 & 20,589 & & \\
\hline
\end{tabular}

\subsection{Principle 4. Environmental Offsets will be Focused on Longer Term Strategic Outcomes}

One of the key deficiencies in mitigation planning is a failure to locate offset actions in places that contribute to broader landscape scale conservation priorities [3,24]. With an estimate of potential impacts, it is possible to set mitigation goals and identify a portfolio of best potential offset options [16]. The aim is to select options that provide ecologically and/or functionally equivalent values to impacted areas, contribute to landscape conservation goals, and will persist at least as long as impacts. While the focus is on long term strategic outcomes it should be emphasized that this could and should include short term objectives relevant and important to particular species, while long term ambitions should not thwart short term outcomes which will inevitably impact upon the goals of longer time scales (e.g., [42]).

To ensure that offsets mitigate on-site impacts, we selected offset sites that contain similar habitats as the mining footprint and in configurations that contribute to conservation goals across the region (Figure 4). We analyzed possible offset designs across two geographic extents: (1) at the landscape level, across an area defined roughly by the East Goldfields subregion; and (2) at the site level, across the Kanowna pastoral leases currently under management control of Barrick Gold. The main purpose of the first landscape-level analysis was to evaluate possible offset designs that contributed the most to conservation priorities across the region. While working on Barrick-held pastoral leases would obviously reduce any logistical constraints, we wanted to confirm that these sites were appropriate as offset sites. We followed an approach developed for regional conservation planning that identifies conservation areas for meeting explicit targets while optimizing for ecological condition and efficiency (minimal area) [43-45]. This involved the following steps: identifying focal biodiversity elements, as described above; setting equivalency based on the amount of each habitat element occurring in the footprint, as described above; and evaluating ecological condition based on an index of disturbance derived from geospatial data of current human disturbance.

The disturbance index summarizes cumulative human impacts (i.e., roads, houses, rail lines, dams) as an indirect measure of ecological integrity, or departure from historic or natural conditions. In selecting offset sites, this index is the basis for maximizing selection of undisturbed ecosystem occurrences. Patterns of existing disturbance have historically played a significant role in the design and development of conservation priorities [46]. Areas of high disturbance generally have lower value 
for biodiversity (e.g., [47,48]). Disturbance is also consistently associated with reduced biological integrity and increased probability of extirpation for many species $[49,50]$.

Figure 4. Identifying the Offset Portfolio. The flow chart illustrates the process and data sources for identifying a set of potential offset sites that contain similar habitat as the mining footprint and in configurations that contribute to conservation goals across the region.

\section{Focal Habitat Elements}
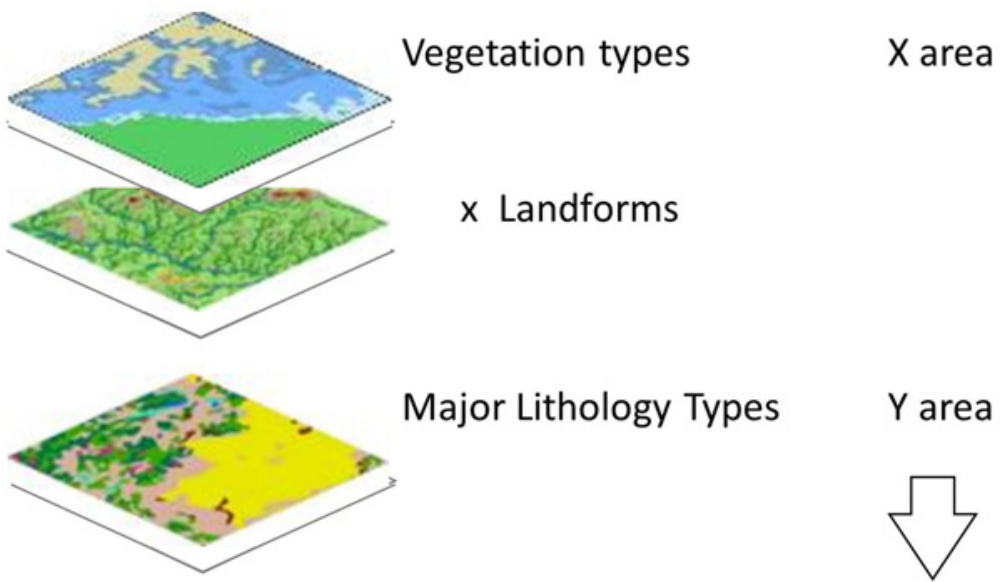

Vegetation types

x Landforms

Major Lithology Types

$\mathrm{X}$ area

\section{Selection Criteria}

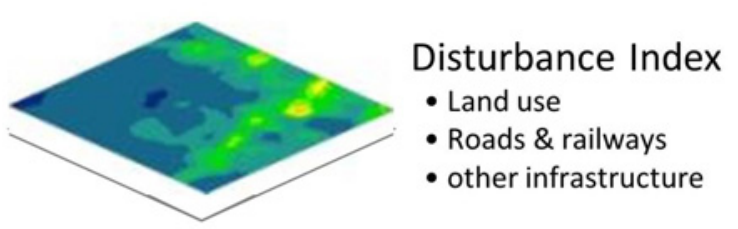

\section{Goals based on area of impact}

\section{Potential offset scenarios}

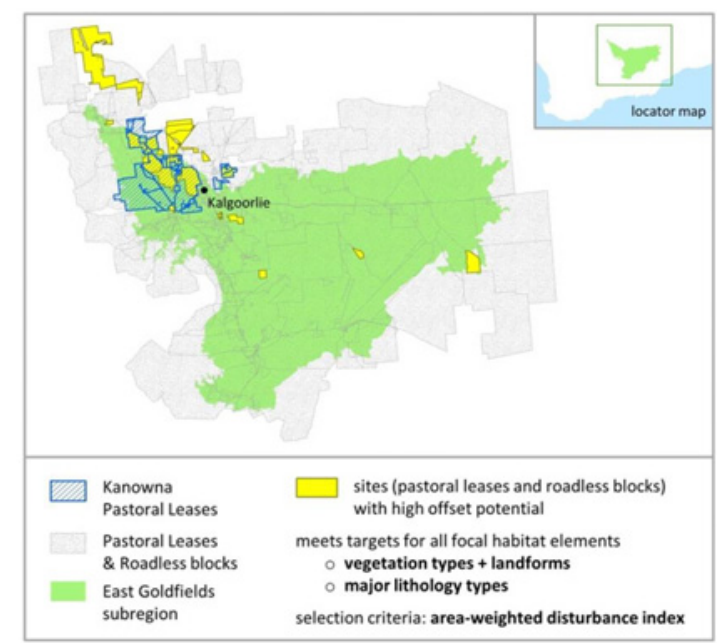

Finally, we evaluated various scenarios, or sets of possible offset sites, that meet equivalency for habitat elements while optimizing for efficiency and condition. We conducted this analysis using the software package MARXAN [51,52], which was designed for conservation planning and allows the integration of many available spatial data sets on land-use patterns and conservation status, and enables a rapid evaluation of alternative configurations. The landscape-level analysis found that a significant portion of the optimal offset sites occur in the area near Kanowna Belle mine operations and within the Barrick Pastoral Leases, which cover $8 \%$ of the East Goldfields subregion and contain $36 \%$ area of the optimal offset sites (Figure 5). For all habitat elements, the pastoral leases contain the same amount or 
more of estimated hectares impacted, meaning ecological equivalency can be met within Barrick-owned pastoral leases.

Figure 5. Landscape level offset siting analysis. The map shows the result of landscape-level analysis across all pastoral leases and roadless blocks intersecting or adjacent to the East Goldfields subregion. The results indicate that the Kanowna pastoral leases include an optimal set of potential sites that meet ecological equivalency for biodiversity elements and would contribute to conservation priorities across the region.

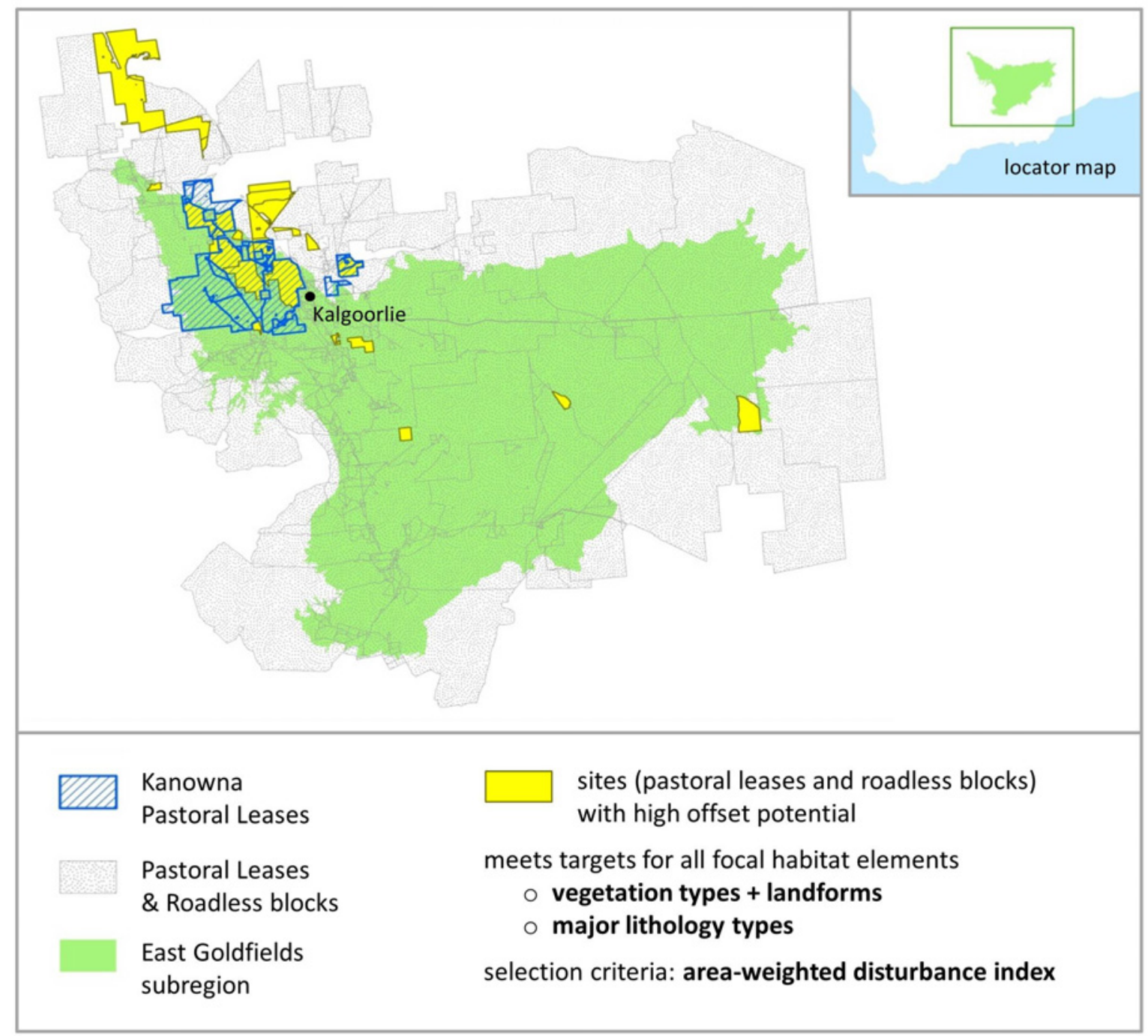

3.5. Principle 5. Environmental Offsets will be Cost-Effective, as well as Relevant and Proportionate to the Significance of the Environmental Value Being Impacted

After identifying a portfolio of the best offset sites we measured the extent to which implementation of mitigation actions will fully address impacts in a manner consistent with landscape-level conservation goals. Among several considerations for measuring success, three important factors include: (a) "additionality" (an options new contribution to conservation, additional to existing values); (b) probability of success (the likelihood that an option will deliver expected conservation benefits); and (c) time-lag to conservation maturity (how long it will take for an option to deliver conservation at 
a maturity level similar to what was lost due to impacts). With an understanding of the conservation value of different mitigation actions, it is possible to compare these values to the cost of implementing the actions to estimate which actions will provide the highest conservation returns on investment.

Assessing progress towards the no net loss goal requires comparison of project impacts and offsets benefits. Of particular importance for the accounting framework are: (a) the "currency", which allows for a "like for like" comparison of project impacts to the offset benefits; (b) discounting, which supports comparison of impacts and benefits occurring during different time periods; and (c) the probability of success and additionality estimates for offset actions [18,20,53,54].

For an accounting currency, we use "hectare-years" to reflect the spatial and temporal elements of impacts and benefits. For example, an impact of 100 ha in Year 1 that continues through Year 2 represents 200 ha-yr of impact at the end of Year 2. An offset that restores 100 ha over five years at a rate of $20 \mathrm{ha} / \mathrm{yr}(20+40+60+80+100)$ provides 300 hectare-years of benefit at the end of Year 5 . The ha-yr currency allows us to compare impacts and benefits for different spatial extents over different periods of time. Further details on how impacts and benefits were calculated at Kanowna Belle are provided in [21].

\section{Potential Offset Actions}

Our analysis indicated that Barrick Gold's pastoral leases provide offset opportunities for management and restoration actions that could potentially deliver a no-net-loss outcome with ecologically equivalent values to what was impacted by mining activities for those biodiversity elements assessed. This assessment was based on a calculation of no-net-loss for impacts associated with the seven year time period between July 2009 (when Barrick adopted their biodiversity standard) and their current estimated mine closure date of 2016 [21].

We proposed offsets actions that target key management issues for the pastoral lease areas that are likely to deliver a high conservation return on investment. Old growth areas within the Woodlands were identified given their high value for species, the limited amount of old growth woodland remaining in the Great Western Woodlands and the risk that fire represents to remaining old growth woodlands [22,55,56]. Given the relative importance of old growth areas for the Great Western Woodlands, we proposed the development and implementation of fire management plans to prevent damaging fires. While it is unlikely that old growth areas were lost as a result of mining activities on the Kanowna Belle sites during Barrick's tenure, these areas add value both from a conservation perspective as well as from an offset valuation perspective. We based our estimate of additionality of a fire management plan, and the implementation of this plan, on the potential for loss associated with severe fires assuming that the past trend in uncontrolled fires is indicative of the potential for future fires and, in turn, additional damage to old growth structure. We assume that without active fire management/prevention fires will continue and additional losses to old growth woodlands will continue.

Mining development and exploration as well as grazing of non-native herbivores are the primary sources of impact to biodiversity within the study area. Thus across the entirety of the Barrick pastoral leases we recommended a bundle of management activities (de-stocking, removing artificial water sources, closing roads/tracks where possible, and removing exploration drill holes) for old growth and 
high and medium condition non-old growth areas (Table 3). These actions are intended to improve the condition of vegetation and remove a major source of mortality for small- and medium-size animals. We also suggested a number of additional offset actions for select areas where more active restoration is needed (i.e., active reseeding or re-planting) in order to improve the condition. Finally we recommended that the pastoral leases be converted to a conservation lease as part of proposed changes to the Western Australian pastoral tenure system, to enable the leases to be managed for the purpose of conservation in the long-term.

Table 3. Distribution of pastoral lease area by habitat type (old growth) and condition (high/medium) and possible offset actions.

\begin{tabular}{|c|c|c|c|}
\hline Actions & $\begin{array}{c}\text { High } \\
158,447 \text { ha }\end{array}$ & $\begin{array}{c}\text { Medium } \\
142,331 \text { ha }\end{array}$ & $\begin{array}{c}\text { Old Growth Woodland } \\
46,998 \text { ha }\end{array}$ \\
\hline Protect old growth through fire management & $\bullet$ & $\bullet$ & $\bullet$ \\
\hline De-stocking pastoral leases & $\bullet$ & $\bullet$ & $\bullet$ \\
\hline Removing artificial water sources (number*) & - (35) & - (64) & - (18) \\
\hline Road closures or track closures & - & $\bullet$ & $\bullet$ \\
\hline Recapping drill holes & $\bullet$ & $\bullet$ & • \\
\hline Control of invasive species (e.g., goats, donkeys, camels) & & - as needed & \\
\hline Control of invasive species (plants) & & - as needed & \\
\hline Non-native predator control & & - as needed & \\
\hline Supplementary faunal habitat & & - as needed & \\
\hline Active restoration (e.g., re-seeding) & & - as needed & \\
\hline
\end{tabular}

* Possible artificial water sources include all water holes, bores, wind pumps and water tanks mapped in GEODATA TOPO 250k (from Geoscience Australia).

\section{Challenges and Solutions}

A number of hurdles and barriers were identified as part of this process, broadly divided into "limitations of data to inform offsetting" and "legal/institutional barriers to implementing offsets". These are outlined below with suggestions for potential solutions.

\subsection{Limitations of Data}

Species distribution data for the Great Western Woodlands, as is the case for many parts of Australia, is not comprehensive and heavily biased towards roads and surveys of potential mine sites. Nor is there a particularly strong knowledge as to habitat preferences at the finer scale that would allow modeling of distribution based on habitat type. Thus measures of ecological equivalence were restricted to habitat surrogates based on mapped vegetation and other landform features. In the absence of further extensive species surveys, expert opinion could be sought to better assign species to fine level habitat types or vegetation units, creating new layers to act as surrogates for distribution (see for example [57]).

Data on the presence of species and quality of habitat as a baseline prior to the establishment of the Kanowna Belle mine site was limited, as it is with many mining operations established before the need for environmental impact assessments. In addition, the Kanowna Belle mine site was in operation 
before Barrick Gold took ownership making attempts to assign impacts to Barrick difficult. Because we assumed there to be native vegetation present, based on the NVIS classification derived from maps of pre-European vegetation, we undoubtedly overestimated impacts associated with direct and indirect surface disturbance associated with Barrick's activities ([35,37]; Figure 2). While new policies enacted by the Australian Government will not apply retrospectively to existing impacts, this case study made it clear that the establishment of baseline conditions will be critical. Finally, like any mining operation, the Kanowna Belle mine site may have some impacts on biodiversity that may not be realised yet but remain as risk and could occur in the future [58]. Mine sites such as Kanowna Belle consist of extractive, processing, workshop and chemical storage areas as well as waste storage areas for materials that will either produce geochemically enriched drainage or simply are highly unstable for geological periods.

\subsection{Legal and Institutional Barriers to Implementing Offsets}

The identified offset area is a set of pastoral leases held by Barrick Gold. Pastoral leasehold tenures occur throughout much of inland Australia and are essentially land owned by the State/Territory Governments leased to private pastoralists for the purpose of broadacre grazing of livestock in mostly native (i.e., unimproved) habitats. The leases are usually long-term (e.g., 99 years) and occur over large properties.

We recognize that the current pastoral lease designation may restrict Barrick Gold in implementing offset recommendations made as part of this analysis. Under the Western Australian Land Administration Act 1997, the primary legislation relevant to pastoral lease management in that state, there are a number of stipulations regarding specific activities that must be undertaken (e.g., the commercial grazing of authorized stock, set minimum stocking rates) even if these are not commercially viable. Many of these stipulations run counter to the conservation-minded management activities that would serve to offset the impacts associated with Barrick's mining activities. Moreover, these stipulations make it difficult to legally secure conservation outcomes on pastoral leases in the Great Western Woodlands. These restrictions are not unusual to Western Australia and indeed are common to pastoral lease holdings across Australia. There have been difficulties in applying conservation mechanisms such as conservation covenants over pastoral leases in many Australian jurisdictions, including Western Australia, affecting the ability to secure permanent protection even if that is the desire of the owner of the lease. However, the Western Australian Government is in the process of exploring new tenure options for rangelands as part of broader rangelands reform. Included as part of the Rangelands Tenure Options Discussion Paper released in April 2011 [59], a new lease type "Conservation Lease" was proposed. While a conservation lease would not preclude mining and exploration, it would remove the requirement to manage a lease as a pastoral property and thus graze the lease with livestock (and provide infrastructure to enable this grazing) and it would recognize conservation as a primary purpose. If a conservation lease mechanism is established by the Western Australian Government, it is recommended that a conservation lease be applied to the Barrick pastoral holdings in order for the offsets to be better secured.

Despite many Australian jurisdictions having sophisticated biodiversity offsetting approaches (e.g., Victoria, New South Wales), their ability to "secure" the offsets from future loss through mining is 
limited to placing land in a national park category or similar [60,61], which is not a viable option in many cases. So what does this mean for the concept of voluntary offsets if the decision to grant a mining permit is outside of the control of the company doing the offset? What does it mean for Barrick's goal of no net loss if the Western Australian mines department grants mining licenses over Barrick's pastoral leases which are to act as an offset for their Kanowna Belle mine?

Long-term security of offset viability is likely to be a common problem and not specific to Western Australia. For example in the western United States, Kiesecker et al. [16] designed offsets intended to compensate for impacts associated with British Petroleum's oil and gas development on the Jonah Field in southwestern Wyoming. The design of offset sites included avoiding areas of high potential oil and gas development. While the use of offsets was part of the regulatory decision making process, siting offsets away from areas of high development potential was critical to maintaining the integrity of the offset for at least as long as impacts are incurred on-site and given the directive of the regulatory agency (US Bureau of Land Management, BLM) to develop petroleum resources. Similar to the pastoral leases in Australia, the BLM is mandated to utilize lands for both livestock grazing and mineral exploitation. Because of the high degree of oil and gas activity in this area, the BLM chose to forgo selection of areas with high future development potential for offsets to prevent the possibility of establishing offset sites that may themselves require offset [62]. Moreover, the high cost and regulatory uncertainty associated with working in areas with high resource potential were additional reasons to avoid selecting these areas. Where resource potential can be predicted this could be a viable solution to maintaining offset security. In situations where this is difficult, offset security will remain a key challenge.

Another question of security arises from the following scenario: If Barrick was to sell the Kanowna Belle mine site and/or adjoining pastoral holdings, would there be an expectation on the new owner of the pastoral lease to undertake the actions committed to by Barrick? In the absence of signing a conservation lease, there would be little to obligate new owners of the pastoral holdings unless conditions could be written into a condition of sale agreement on the lease. Another option may be to have the offset registered on a publicly accessible offset register. For example, under the proposed Western Australian offset policy, an Offsets Register "will provide a public record of all offset agreements in Western Australia in a centralised form, (including) all offsets that may have been negotiated by different agencies under different legislation" [11]. However, there is uncertainty as to whether a voluntary offset will be recognized as such under formalized offsetting registers.

These policy questions (and others raised by [2,18,42,63-65]) must be resolved by government in this rapidly evolving field if the confidence in security of offsets, be they required under regulation or voluntary, is to be maintained.

\section{Conclusions}

Governments, and increasingly companies, are seeking options and transparent processes that will result in no net loss of biodiversity values impacted by mining operations. Australia is undergoing a mining boom and many jurisdictions are still in the process of developing and testing their different policies and regulations. Our analysis highlights some of the key challenges that will be critical to uncover and disentangle if the use of offsets is to deliver on its intended goal. 


\section{Acknowledgments}

We thank external independent members of the project Working Group for providing their time and expertise to this process: Keith Bradby, Neil Gibson, Ric How, Ian Kealley, Amanda Keesing, Peter Price, Suzanne Prober and Wayne O'Sullivan. Megan Evans and Mark Cowan also provided important feedback and data. Melissa Barbanell, Allison Brown, Adrian Lally, Ben Wither, and Gail Ross from Barrick Gold are thanked for engaging in the process and providing data and feedback. We would also like to thank Amy Middleton, David Wood and Janssen Volker for helpful discussion. All assumptions are ours and do not necessarily represent the views of the above mentioned people. The comments of two anonymous referees greatly improved the manuscript.

\section{Author Contributions}

All authors were involved with the design of the project, analysis of data and writing of the manuscript.

\section{Conflicts of Interest}

The authors declare no conflict of interest.

\section{References}

1. Ten Kate, K.; Bishop, J.; Bayon, R. Biodiversity Offsets: Views, Experience, and the Business Case; International Union for Conservation of Nature: Gland, Switzerland/Cambridge, UK, and Insight Investment: London, UK, 2004.

2. Gibbons, P.; Lindenmayer, D. Offsets for land clearing: No net loss or the tail wagging the dog? Ecol. Manage. Restor. 2007, 8, 26-31.

3. McKenney, B.; Kiesecker, J.M. Policy development for biodiversity offsets: A review of offset frameworks. Environ. Manage. 2010, 45, 165-176.

4. Council on Environmental Quality. Protection of the Environment (under the National Environmental Policy Act); Report No. 40 CFR 1500-1517; Council on Environmental Quality: Washington, DC, USA, 2000.

5. New South Wales Department of Environment and Climate Change. BioBanking Biodiversity Banking and Offsets Scheme: Scheme Overview; Department of Environment and Climate Change: Sydney, NSW, Australia, 2007.

6. Environmental Defense. Mitigation Banking as an Endangered Species Conservation Tool; Environmental Defense: Washington, DC, USA, 1999.

7. Madsen, B.; Carrol, N.; Kandy, D.; Bennett, G. State of Biodiversity Markets Report: Offset and Compensation Programs Worldwide. Forest Trends: Washington, DC, USA, 2011.

8. International Finance Corporation. Performance Standard 6. Biodiversity Conservation and Sustainable Management of Living Natural Resources; World Bank Group: Washington, DC, USA, 2012.

9. Rio Tinto. Rio Tinto's Biodiversity Strategy; Rio Tinto: London, UK/Melbourne, VIC, Australia, 2004. 
10. Environmental Law Institute (ELI). Mitigation of Impacts to Fish and Wildlife Habitat: Estimating Costs and Identifying Opportunities; ELI: Washington, DC, USA, 2007.

11. Western Australian Government. WA Environmental Offsets Policy; Western Australian Government: Perth, WA, Australia, 2011. Available online: http://www.epa.wa.gov.au/ EPADocLib/WAEnvOffsetsPolicy-270911.pdf (accessed on 1 July 2013).

12. Department of Sustainability, Environment, Water, Population and Communities (DSEWPC). Environment Protection and Biodiversity Conservation Act 1999 Environmental Offsets Policy; DSEWPC: Canberra, ACT, Australia, 2012.

13. Golden Ridge Limited. BBOP Pilot Project Case Study. Akyem Gold Mining Project, Eastern Region, Ghana. Newmont Golden Ridge Limited: Accra, Ghana, 2009. Available online: www.forest-trends.org/biodiversityoffsetprogram/guidelines/newmont-casestudy.pdf (accessed on 1 July 2013).

14. Barrick. Building Value in Everything We Do: Annual Report 2010; Barrick: Toronto, ON, Canada, 2010.

15. Barrick. Available: http://barrickresponsibility.com/2009/en/environment/biodiversity.html (accessed on 7 July 2013).

16. Kiesecker, J.M.; Copeland, H.; Pocewicz, A.; Nibbelink, N.; McKenney, B.; Dahlke, J.; Holloran, M.; Stroud, D. A framework for implementing biodiversity offsets: selecting sites and determining scale. BioScience 2009, 59, 77-84.

17. Norton, D. Biodiversity offsets: two New Zealand case studies and an assessment framework. Environ. Manage. 2009, 43, 698-706.

18. Moilanen, A.; van Teefelen, A.J.A.; Ben-Haim, Y.; Ferrier, S. How much compensation is enough? A framework for incorporating uncertainty and time discounting when calculating offset ratios for impacted habitat. Restor. Ecol. 2009, 17, 470-478.

19. Treweek, J.; Butcher, B.; Temple, H. Biodiversity offsets: Possible methods for measuring biodiversity losses and gains for use in the UK. Practice 2010, 69, 29-32.

20. Quetier, F.; Lavorel, S. Assessing ecological equivalence in biodiversity offset schemes: Key issues and solutions. Biol. Conserv. 2012, 144, 2991-2999.

21. Kiesecker, J.; Heiner, M.; Sochi, K.; McKenney, B.; Fitzsimons, J. Development by Design: Cooperative Mitigation Planning for Barrick Gold's Kanowna Belle Operations in Western Australia; The Nature Conservancy: Fort Collins, CO, USA, 2013. Available online: http://www.nature.org/ourinitiatives/urgentissues/smart-development/australia-project-update -smart-development.pdf (accessed on 13 October 2013).

22. Watson, A.; Judd, S.; Watson, J.; Lam, A.; Mackenzie, D. The Extraordinary Nature of the Great Western Woodlands; The Wilderness Society of WA Inc: Perth, WA, Australia, 2008.

23. Australian Government. Available online: http://www.environment.gov.au/parks/nrs/science/ bioregion-framework/ibra/index.html (accessed on 25 July 2012).

24. Kiesecker, J.M.; Copeland, H.; Pocewicz, A.; McKenney, B. Development by design: Blending landscape level planning with the mitigation hierarchy. Front. Ecol. Environ. 2010, 8, 261-266.

25. Kiesecker, J.M.; Sochi, K.; Heiner, M.; McKenney, B.; Evans, J.; Copeland, H. Development by Design: Using a Revisionist History to Guide a Sustainable Future. In Encyclopedia of Biodiversity, 2nd ed.; Levin, S.A., Ed.; Academic Press: Waltham, MA, USA, 2013; pp. 495-507. 
26. Kiesecker, J.M.; Copeland, H.; McKenney, B.; Pocewicz, A; Doherty, K. Energy by Design: Making Mitigation Work for Conservation and Development. In Energy Development and Wildlife Conservation in Western North America; Naugle, D.E., Ed.; Island Press: Washington, DC, USA, 2011; pp. 159-181.

27. Environment Protection Authority. Gold Roaster to Treat Refractory Ore, Kanowna Belle Mine, Stage 2, 18 km North East of Kalgoorlie; Bulletin 710; Environment Protection Authority: Perth, WA, Australia, 1993.

28. Clare, S.; Krogman, N.; Foote, L.; Lemphers, N. Where is the avoidance in the implementation of wetland law and policy? Wetlands Ecol. Manage. 2011, 19, 165-182.

29. Pilgrim, J.D.; Brownlie, S.; Ekstrom, J.M.M.; Gardner, T.A.; von Hase, A.; Ten Kate, K.; Savy, C.E.; Stephens, R.T.T.; Temple, H.J.; Treweek, J.; et al. A process for assessing the offsetability of biodiversity impacts. Conserv. Lett. 2013, 6, 376-384.

30. Pressey, R.L.; Bottrill, M.C. Opportunism, threats, and the evolution of systematic conservation planning. Conserv. Biol. 2008, 22, 1340-1345.

31. Copeland, H.E.; Doherty, K.E.; Naugle, D.E.; Pocewicz, A.; Kiesecker, J.M. Mapping oil and gas development potential in the US Intermountain West and estimating impacts to species. PLoS ONE 2009, 4, e7400.

32. Thorne, J.H.; Huber, P.R.; Girvetz, E.H.; Quinn, J.; McCoy, M.C. Integration of regional mitigation assessment and conservation planning. Ecol. Soc. 2009, 14, 47-63.

33. Saenz, S.; Walschburger, T.; León, J.; Gonzalez, J. Manual Para Asignación de Compensaciones por Pérdida de Biodiversidad; Convenio de Asociación No.09 de 2008; Ministerio de Ambiente, Vivienda y Desarrollo Territorial/The Nature Conservancy/World Wildlife Fund/Conservación Internacional: Bogota, Colombia, 2010.

34. Heiner, M.; Galbadrakh, D.; Kiesecker, J.M.; McKenney, B.; Evans, J.; Enkhtsetseg, T.; Dash, Z.; Vanchindorj, U.; Baast, O.; Dolgorjav, S.; et al. Identifying Conservation Priorities in the Face of Future Development: Applying Development by Design in the Grasslands of Mongolia; The Nature Conservancy: Fort Collins, CO, USA, 2011.

35. Executive Steering Committee for Australian Vegetation Information. Australian Vegetation Attribute Manual: National Vegetation Information System, Version 6.0; Department of the Environment and Heritage: Canberra, ACT, Australia, 2003.

36. Stewart, A.J.; Sweet, I.P.; Needham, R.S.; Raymond, O.L.; Whitaker, A.J.; Liu, S.F.; Phillips, D.; Retter, A.J.; Connolly, D.P.; Stewart, G. Surface Geology of Australia 1:1,000,000 Scale, Western Australia (Digital Dataset); Geoscience Australia: Canberra, ACT, Australia, 2008.

37. Beard, J.S.; Webb, M.J. The Vegetation Survey of Western Australia: Its Aims, Objects and Methods. In Vegetation Survey of Western Australia. Part 1 of Explanatory Notes to Sheet 2-Great Sandy Desert; University of Western Australia Press: Perth, WA, Australia, 1974.

38. Rich, P.M.; Hetrick, W.A.; Saving, S.C. Modeling Topographic Influences on Solar Radiation: A Manual for the SOLARFLUX Model, LA-12989-M; Los Alamos National Laboratories: Los Alamos, NM, USA, 1995.

39. Moore, I.D.; Grayson, R.B.; Ladson, A.R. Digital terrain modelling: A review of hydrological, geomorphological, and biological applications. Hydrol. Process. 1991, 5, 3-30. 
40. Morton, S.R.; James, C.D. The diversity and abundance of lizards in arid Australia: A new hypothesis. Amer. Nat. 1988, 132, 237-256.

41. Hebblewhite, M. A Literature Review of the Effects of Energy Development on Ungulates: Implications for Central and Eastern Montana; Report prepared for Montana Fish, Wildlife and Parks: Miles, MT, USA, 2008.

42. Maron, M.; Dunn, P.K.; McAlpine, C.A.; Apan, A. Can offsets really compensate for habitat removal? The case of the endangered red-tailed black-cockatoo. J. Appl. Ecol. 2010, 47, 348-355.

43. Groves, C.; Jensen, D.; Valutis, L.; Redford, K.; Shaffer, M.; Scott, J.; Baumgartner, J.; Higgins, J.; Beck, M.; Anderson, M. Planning for biodiversity conservation: Putting conservation science into practice. BioScience 2002, 52, 499-512.

44. Groves, C. Drafting a Conservation Blueprint: A Practitioner's Guide to Planning for Biodiversity; Island Press: Washington, DC, USA, 2003.

45. Higgins, J.; Esselman, R. Ecolregional Assessment and Biodiversity Toolbox, 2006. Available online: $\quad$ http://www.conservationgateway.org/Files/Pages/ecoregional-assessment-to.aspx (accessed on 31 January 2012).

46. Margules, C.R.; Pressey, R.L. Systematic conservation planning. Nature 2000, 405, 243-53.

47. Forman, R.T.T.; Sperling, D.; Bissonette, J.A.; Clevenger, A.P.; Cutshall, C.D.; Dale, V.H.; Fahrig, L.; France, R.L.; Goldman, C.R.; Heanue, K.; et al. Road Ecology: Science and Solutions; Island Press: Washington, DC, USA, 2002.

48. Fletcher, R.J.; Robertson, B.A.; Evans, J.; Doran, P.J.; Alavalapati, J.R.; Schemske, D.W. Biodiversity conservation in the era of biofuels: Risks and opportunities. Front. Ecol. Environ. 2011, 9, 161-168.

49. Johnson, C.J.; Boyce, M.S.; Case, R.L.; Cluff, H.D.; Gau, R.J.; Gunn, A.; Mulders, R. Cumulative effects of human developments on Arctic wildlife. Wildl. Monogr. 2005, 160, 1-36.

50. Vors, L.S.; Schaefer, J.A.; Pond, B.A.; Rodgers, A.R.; Patterson, B.R. Woodland caribou extirpation and anthropogenic landscape disturbance in Ontario. J. Wildl. Manage. 2007, 71, 1249-1256.

51. Ball, I.R.; Possingham, H.P. MARXAN (V1.8.2): Marine Reserve Design Using Spatially Explicit Annealing-A Manual; 2000. Available online: http://www.uq.edu.au/marxan/docs/ marxan_manual_1_8_2.pdf (accessed on 25 July 2012).

52. Possingham, H.P.; Ball, I.R; Andelman, S. Mathematical Methods for Identifying Representative Reserve Networks. In Quantitative Methods for Conservation Biology; Ferson, S.; Burgman, M., Eds.; Springer-Verlag: New York, NY, USA, 2000; pp. 291-305.

53. Burgin, S. BioBanking: An environmental scientist's view of the role of biodiversity banking offsets in conservation. Biodivers. Conserv. 2008, 17, 807-816.

54. Fox, J.; Nino Murcia, A. Status of species conservation banking in the United States. Conserv. Biol. 2005, 19, 996-1007.

55. Daniel, G. Bushfire Threat Analysis of the Great Western Woodlands; Department of Environment and Conservation: Perth, WA, Australia, 2010

56. O’Donell, A.J.; Boer, M.M.; McCaw, W.L.; Grierson, P.F. Vegetation and landscape connectivity control wildfire intervals in unmanaged semi-arid shrublands and woodlands in Australia. $J$. Biogeog. 2010, 38, 112-124. 
57. Fitzsimons, J.A.; Peake, P.; Frood, D.; Mitchell, M.; Withers, N.; White, M.; Webster, R. Flooding requirements for biodiversity values along the Victorian floodplain of the Murray Valley. Victorian Nat. 2011, 128, 48-85.

58. Jones, H.; Salmon, D. Unintended Consequences and Mine Closure. In Mine Closure 2012: Proceedings of the International Mine Closure 2012 Congress, Brisbane, Australia; Fourie, A.B., Tibbett, M., Eds.; Australian Centre for Geomechanics: Perth, WA, Australia, 2012; pp. 703-716.

59. Department of Regional Development and Lands (DRDL). Rangelands Tenure Options Discussion Paper April 2011; DRDL: Perth, WA, Australia, 2011.

60. Niewand, G.; Fitzsimons, J. Earth Resources Activities on Crown Land: Guidelines and Procedures for Land Managers; Department of Sustainability and Environment: Melbourne, VIC, Australia, 2005.

61. Adams, V.M.; Moon, K. Security and equity of conservation covenants: Contradictions of private protected area policies in Australia. Land Use Policy 2013, 30, 114-119.

62. US Bureau of Land Management. Record of Decision for the Jonah Infill Drilling Project Environmental Impact Statement; Department of the Interior, Bureau of Land Management Pinedale Field Office: Pinedale, WY, USA, 2006.

63. Morris, R.K.A.; Alonso, I.; Jefferson, R.G.; Kirby, K.J. The creation of compensatory habitat - Can it secure sustainable development? J. Nature Conserv. 2006, 14, 106-116.

64. Maron, M.; Hobbs, R.; Moilanen, A.; Matthews, J.W.; Christie, K.; Gardner, T.A.; Keith, D.A.; Lindenmayer, D.B.; McAlpine, C.A. Are restoration offsets Faustian bargains? Restoration realities in the context of biodiversity offset policies. Biol. Conserv. 2012, 155, 141-148.

65. Walker, S.; Brower, A.L.; Stephens, R.T.; Lee, W.G. Why bartering biodiversity fails. Conserv. Lett. 2009, 2, 149-157.

(C) 2014 by the authors; licensee MDPI, Basel, Switzerland. This article is an open access article distributed under the terms and conditions of the Creative Commons Attribution license (http://creativecommons.org/licenses/by/3.0/). 